\title{
Pengaruh Model CLIS Terhadap Hasil Belajar Siswa pada Materi Larutan Elektrolit dan Non Elektrolit
}

\section{The Influences of the CLIS Model Used in Students Learning Outcomes on Electrolyte and Nonelectrolyte Solutions}

\author{
A Aulia ${ }^{1}$ and A Ulianas ${ }^{1 *}$ \\ 1 Pendidikan Kimia, Universitas Negeri Padang, Jl. Prof. Dr. Hamka, Air Tawar Barat, \\ Padang Utara, Sumatera Barat, Indonesia 25171 \\ *alizar_chem@yahoo.co.id
}

\section{ARTICLE INFO}

Received 30 May 2020

Revised 24 June 2020

Published 03 July 2020

\begin{abstract}
An experimental research using the Children Learning In Science (CLIS) model has been conducted to figure out learning outcome. The research sample involved two classes with different learning model. The first class model used the CLIS model as experimental class while the second class model used the conventional model as a control class. Multiple choice questions were the research instrument to measure students achievement in cognitive aspect. The results showed that the average of the experimental class was 85,29 and the control class was 78,43. The study showed that the CLIS model has positive and significant influence on the student learning outcomes.
\end{abstract}

\section{KEYWORDS}

Children Learning In Science, Learning Outcomes, t-test

\section{ABSTRAK}

Penelitian eksperimen menggunakan model Children Learning In Science (CLIS) telah dilakukan untuk mencari tahu hasil belajar. Sampel penelitian mencakup dua kelas dengan model pembelajaran berbeda. Kelas pertama menggunakan model CLIS sebagai kelas eksperimen sementara kelas kedua menggunakan model konvensional sebagai kelas kontrol. Soal tes pilihan ganda merupakan instrumen penelitian yang dipakai untuk mengukur hasil belajar pada aspek kognitif. Hasil penelitian memperlihatkan bahwa nilai rata-rata hasil belajar kelas eksperimen sebesar 85,29 dan kelas kontrol sebesar 78,43. Studi ini memperlihatkan bahwa model CLIS dapat memberikan pengaruh positif dan signifikan terhadap hasil belajar siswa.

\section{KATA KUNCI}

Children Learning In Science, Hasil Belajar Siswa, Uji-t 


\section{PENDAHULUAN}

Peningkatan kemampuan manusia dibutuhkan seiring dengan perkembangan waktu dan kebutuhan masyarakat. Salah satu upaya untuk meluaskan kemampuan manusia melalui pendidikan yang diperoleh lewat pembelajaran yang bermutu ${ }^{[1]}$. Mutu dan taraf pendidikan dapat dicermati dari hasil belajar siswa. Pengetahuan konsep, kapabilitas proses, menghasilkan daya cipta, pembentukan perilaku dan penerapan ide dalam kehidupan seharihari merupakan lima cakupan yang memengaruhi mutu pendidikan ${ }^{[2]}$.

Kualitas pendidikan dapat ditingkatkan melalui langkah-langkah pembelajaran atau interelasi antara guru dan siswa ${ }^{[3]}$. Bersumber pada hasil pengamatan yang sudah dilaksanakan di kelas $X$ MIA SMAN 1 Padang, guru mengajar memakai conventional learning model seperti metode ceramah, dan diskusi. Siswa masih banyak diam dalam pelaksanaan pembelajaran, hanya beberapa siswa yang antusias. Hal tersebut membuat siswa jenuh dalam mengiringi proses pembelajaran, sehingga berimbas pada kurang maksimalnya learning outcomes siswa, hal ini terlihat dari persentase kelulusan nilai standar kompetensi semester gasal tahun ajaran 2019/2020, hanya $41 \%$ yang lulus dari nilai standar kompetensi yang telah disepakati guru yaitu sebesar 80 .

Model CLIS merupakan model pembelajaran yang bisa membangkitkan perubahan konseptual siswa melalui beberapa tahapan. Karakteristik yang dimiliki oleh model pembelajaran CLIS ialah siswa yang menjadi orientasi dari pembelajaran, pembelajaran yang memperhatikan situasi dan ide awal siswa, serta menjadikan lingkungan sebagai sumber mencari ilmu dengan dilandasi oleh pandangan konstruktivisme ${ }^{[5]}$.

Kegiatan siswa dalam model CLIS lebih ditekankan untuk mendapatkan ide-ide yang sempurna, menyelaraskan dengan ilmu pengetahuan yang ada, siswa mengungkapkan pendapatnya sendiri sehingga dapat mendiskusikan dan memecahkan masalah yang muncul sebelum guru menyerahkan penuntasan ide-ide ilmiah, serta siswa dibimbing untuk membangun ide baru atau ide yang lebih rasional ${ }^{[3]}$. Terlihat pada langkahlangkah pembelajaran model CLIS pada Tabel 1 .

Tabel 1. Sintaks Pembelajaran Model CLIS ${ }^{[5]}$.

\begin{tabular}{c|l}
\multicolumn{1}{c|}{ Tahapan } & \multicolumn{1}{|c}{ Deskripsi } \\
\hline Orientation & $\begin{array}{l}\text { Guru memusatkan perhatian } \\
\text { siswa pada materi pembelajaran, } \\
\text { guru mengaitkan topik } \\
\text { pembelajaran yang sedang } \\
\text { dieksplorasi dengan fenomena } \\
\text { pada lingkungan sekitar. }\end{array}$ \\
\hline
\end{tabular}

\begin{tabular}{l|l}
\multicolumn{1}{c|}{ Tahapan } & \multicolumn{1}{c}{ Deskripsi } \\
\hline $\begin{array}{l}\text { Elicitation of } \\
\text { ideas }\end{array}$ & $\begin{array}{l}\text { Guru menuntun siswa untuk } \\
\text { mencatatkan apa saja yang } \\
\text { mereka ketahui mengenai } \\
\text { topik pembelajaran yang akan } \\
\text { diulas, guna mengeksplorasi } \\
\text { pengetahuan awal siswa. }\end{array}$ \\
\hline $\begin{array}{l}\text { Restructuring } \\
\text { of ideas }\end{array}$ & $\begin{array}{l}\text { Pemaparan dan peralihan idea, } \\
\text { pembukaan pada situasi konflik, } \\
\text { dan menyusun idea baru. }\end{array}$ \\
\hline $\begin{array}{l}\text { Application of } \\
\text { ideas }\end{array}$ & $\begin{array}{l}\text { Guru menuntun siswa } \\
\text { mengaplikasikan gagasan baru } \\
\text { untuk mengkaji isu-isu ilmiah } \\
\text { dan menyelesaikan persoalan } \\
\text { yang ada di area sekitar. }\end{array}$ \\
\hline $\begin{array}{l}\text { Review change } \\
\text { in ideas }\end{array}$ & $\begin{array}{l}\text { Guru memberikan tindak } \\
\text { lanjut terhadap siswa untuk } \\
\text { memperluas konsep ilmiah siswa. }\end{array}$
\end{tabular}

Model Children Learning In Science (CLIS) membuat siswa berpartisipasi aktif dalam pembelajaran dibandingkan siswa dengan model konvensional siswa hanya memperhatikan paparan guru dan pasif sewaktu kegiatan pembelajaran, sehingga learning outcomes siswa dengan CLIS model lebih tinggi dibandingkan conventional model ${ }^{[4]}$.

\section{METODE}

Penelitian ini termasuk penelitian eksperimen yang bertujuan untuk meninjau learning outcomes siswa yang diberi perlakuan berbeda antara experimental class dan control class. Populasi penelitian adalah seluruh kelas X MIA SMAN 1 Padang dengan sampel kelas $\mathrm{X}$ MIA 2 sebagai control class (conventional learning model) dan kelas X MIA 3 sebagai experimental class (Children Learning In Science learning model). Desain penelitian ini ialah The Randomized Posttest Only Control Group Design, dengan struktur desain penelitian seperti Tabel 2.

Tabel 2. Struktur Desain Penelitian ${ }^{[6]}$.

\begin{tabular}{c|c|c} 
Kelas sampel & Perlakuan & Tes akhir \\
\hline $\mathrm{A}$ & $\mathrm{X}_{1}$ & $\mathrm{~T}$ \\
\hline $\mathrm{B}$ & $\mathrm{X}_{2}$ & $\mathrm{~T}$
\end{tabular}

Keterangan :

A: Kelas model 1 (X MIA 3)

B: Kelas model 2 (X MIA 2)

$\mathrm{X}_{1}$ : CLIS model

$\mathrm{X}_{2}$ : Conventional model

T: Hasil final test pada kelas sampel

Pada tahap pelaksanaannya, 2 kelas yang digunakan sebagai kelas model 1 dan kelas model 2 diberikan model pembelajaran yang berbeda. Kelas model 1 belajar memakai model CLIS dan kelas model 2 belajar memakai model konvensional. Di akhir pembelajaran diberikan 
tes mengenai larutan elektrolit dan non elektrolit berbentuk objective test dengan format multiple choice item untuk kedua kelas.

Data penelitian berupa learning outcomes pada materi larutan elektrolit dan non elektrolit diperoleh dengan alat tes learning outcomes berupa soal pilihan ganda. Normality test dan homogeneity test dilakukan untuk melihat apakah kedua kelas tersebut memiliki varian yang sama serta mengetahui data yang normal dari kedua kelas. Jika normal dan homogen, pengujian berikutnya dengan uji-t pada alpha 0,05. Syarat pengujian hipotesis diterima apabila $\mathrm{H}_{0}$ ditolak dengan harga $\mathrm{t}_{\text {hitung }}>\mathrm{t}_{\text {tabel }}{ }^{[7]}$.

\section{HASIL DAN DISKUSI}

\subsection{Hasil Belajar}

Hasil belajar siswa di akhir pembelajaran pada kedua kelas seperti yang ditunjukkan pada Tabel 3 .

Tabel 3. Nilai Rata-rata, Standar Deviasi dan Varian Kelas Sampel.

\begin{tabular}{c|c|c} 
& Kelas A & Kelas B \\
\hline $\mathbf{N}$ & 35,00 & 35,00 \\
\hline $\bar{X}$ & 85,29 & 78,43 \\
\hline $\mathbf{S}$ & 8,91 & 11,68 \\
\hline $\mathbf{S}^{2}$ & 79,33 & 136,43
\end{tabular}

Dari Tabel 4 terlihat bahwa nilai terendah yang diperoleh siswa pada kelas A dengan menerapkan model CLIS adalah 70 sebanyak dua orang dengan skor 14 dan nilai tertinggi 100 sebanyak lima orang dengan skor 20. Pada kelas B yang memperoleh nilai terendah 60 sebanyak satu orang dengan skor 12 dan nilai tertinggi 100 sebanyak tiga orang dengan skor 20.

Tabel 4. Deskripsi Data Hasil Final Test Kelas Sampel.

\begin{tabular}{c|c|c|c} 
Skor & Nilai & Kelas A & Kelas B \\
\hline 12 & 60 & - & 1 \\
\hline 13 & 65 & - & 8 \\
\hline 14 & 70 & 2 & 4 \\
\hline 15 & 75 & 6 & 4 \\
\hline 16 & 80 & 6 & 5 \\
\hline 17 & 85 & 7 & 4 \\
\hline 18 & 90 & 7 & 5 \\
\hline 19 & 95 & 2 & 1 \\
\hline 20 & 100 & 5 & 3
\end{tabular}

\subsection{Analisis Data}

\subsubsection{Uji Normalitas}

Data penelitian terlebih dahulu diuji normalitas dan homogenitasnya. Untuk uji normalitas, kriteria pengambilan keputusan menggunakan uji Liliefors, jika $\mathrm{L}_{0}<\mathrm{L}_{\text {tabel }}$ pada alpha $0,05^{[7]}$. Berdasarkan hasil final test terdapat normality test pada kedua kelas sampel seperti Tabel 5 .

Tabel 5. Hasil Uji Normalitas Final Test.

\begin{tabular}{c|c|c} 
& Kelas A & Kelas B \\
\hline $\mathbf{N}$ & 35,0000 & 35,0000 \\
\hline $\mathbf{a}$ & 0,0500 & 0,05000 \\
\hline $\mathbf{L}_{\mathbf{0}}$ & 0,1236 & 0,1362 \\
\hline $\mathbf{L}_{\text {tabel }}$ & 0,1498 & 0,1498 \\
\hline Keterangan & Normal & Normal
\end{tabular}

\subsubsection{Uji Homogenitas}

Homogenitas sampel dianalisis dengan uji $\mathrm{F}$ dan kriteria pengambilan keputusan bila $\mathrm{F}_{0}<\mathrm{F}_{\text {tabel }}$ pada alpha $=0,05^{[7]}$. Pada Tabel 6 dapat dilihat hasil homogeneity test kelas sampel.

Tabel 6. Hasil Uji Homogenitas Final Test.

\begin{tabular}{c|c|c} 
& Kelas A & Kelas B \\
\hline $\mathbf{N}$ & 35,00 & 35,00 \\
\hline $\mathbf{S}^{\mathbf{2}}$ & 79,33 & 136,43 \\
\hline $\mathbf{F}_{\text {hitung }}$ & \multicolumn{2}{|c}{1,72} \\
\hline $\mathbf{F}_{\text {tabel }}$ & \multicolumn{2}{|c}{1,77} \\
\hline Keterangan & \multicolumn{2}{|c}{ Homogen }
\end{tabular}

\subsubsection{Uji Hipotesis (Uji-t)}

Uji hipotesis ditentukan dengan uji-t, karena terdistribusi normalnya hasil belajar dan homogennya varian hasil belajar dari kelas model 1 dan kelas model 2. Hipotesis statistik yaitu:

$\mathrm{H}_{0}: \mu 1$ (skor rerata kelas model 1 ) $\leqslant \mu 2$ (skor rerata kelas model 2)

$H_{1}: \mu 1$ (skor rerata kelas model 1$)>\mu 2$ (skor rerata kelas model 2)

Kriteria pengambilan keputusan adalah diterima jika $\mathrm{H}_{0}$ ditolak apabila harga $\mathrm{t}_{\text {hitung }}>\mathrm{t}_{\text {tabel }}{ }^{[7]}$.

Uji hipotesis dapat dilihat pada Tabel 7 .

Tabel 7. Uji Hipotesis Tes Akhir.

\begin{tabular}{c|c|c} 
& Kelas A & Kelas B \\
\hline $\mathbf{N}$ & 35,00 & 35,00 \\
\hline $\bar{X}$ & 85,29 & 78,43 \\
\hline $\mathbf{S}^{2}$ & 79,33 & 136,43 \\
\hline $\mathbf{t}_{\text {hitung }}$ & \multicolumn{2}{|c}{2,76} \\
\hline $\mathbf{t}_{\text {tabel }}$ & \multicolumn{2}{|c}{1,66}
\end{tabular}


$\mathrm{H}_{0} \quad$ ditolak karena $\mathrm{t}_{\text {hitung }}>\mathrm{t}_{\text {tabel }}$, artinya hasil belajar dengan model CLIS secara signifikan lebih tinggi daripada model konvensional. Learning outcomes siswa yang berbeda disebabkan karena pada kelas model 1 diterapkannya model pembelajaran CLIS yang mewujudkan siswa lebih antusias dan memiliki minat belajar dalam proses pembelajaran ${ }^{[5]}$. Salah satu faktor internal yang memengaruhi learning outcomes ialah minat belajar. Semakin tinggi minat belajar siswa, maka akan semakin tinggi attention/antusias siswa dalam pembelajaran, sehingga dapat menimbulkan keberhasilan dalam pembelajaran ${ }^{[12]}$.

Keunikan model pembelajaran CLIS ialah berdasarkan pandangan konstruktivisme yang memiliki sintaks untuk membangun perubahan konseptual siswa, sehingga center dari pembelajaran adalah siswa ${ }^{[5]}$. Melalui hasil observasi atau percobaan, model CLIS dapat meluaskan idea siswa tentang suatu persoalan dalam pembelajaran, sehingga siswa bisa memperbaiki gagasan yang bersumber pada hasil observasi atau percobaan tersebut ${ }^{[8]}$.

Orientasi, pemunculan gagasan, penyusunan ulang gagasan, penerapan gagasan, serta pemantapan gagasan merupakan lima tahapan model pembelajaran CLIS $^{[9]}$. Pada tahap orientasi guru menunjukkan fenomena dalam kehidupan lingkungan sekitar yang berhubungan dengan pokok pembelajaran ${ }^{[5]}$. Dalam pelaksanaan penelitian, guru menunjukkan fenomena dengan bantuan slide power point. Di mana guru menampilkan fenomena mengenai gambar pemadaman arus listrik.

Tahap selanjutnya yaitu pemunculan gagasan. Pada tahap ini guru mengupayakan untuk memunculkan gagasan awal siswa tentang pokok pembelajaran yang dikaji dalam pembelajaran, dengan cara mengajak siswa untuk mencatatkan apa saja yang mereka ketahui mengenai pokok pembelajaran yang dibahas ${ }^{[8]}$. Dalam pelaksanaan penelitian pada tahap ini, guru membagi siswa ke dalam beberapa kelompok diskusi untuk membahas topik pembelajaran.

Tahap selanjutnya ialah tahap penyusunan ulang gagasan yang dikhususkan menjadi tiga komponen diantaranya; pemaparan dan peralihan gagasan, pembukaan pada situasi konflik, dan menyusun gagasan baru ${ }^{[5]}$.

Dalam pelaksanaan penelitian pada tahap pemaparan dan peralihan gagasan, guru memperjelas gagasan awal yang telah didapat siswa pada saat mendiskusikan topik pembelajaran, yang mana masing-masing perwakilan anggota kelompok diskusi memberitahukan hasil diskusi ke seluruh kelas. Selanjutnya guru tidak membetulkan atau pun tidak menyalahkan idea yang telah didiskusikan oleh siswa. Kemudian pada tahap pembukaan pada situasi konflik, guru memberikan kesempatan kepada siswa untuk mencari scientific definition terkait topik pembelajaran yang sedang dibahas, baik dari buku cetak atau sumber lainnya. Kemudian pada tahapan menyusun ulang gagasan baru, guru mencocokkan gagasan yang telah diperoleh siswa dengan peristiwa-peristiwa yang dipelajari sehingga memperoleh suatu new idea.

Tahapan berikutnya ialah tahap penerapan gagasan. Ide baru yang sudah dikembangkan oleh siswa dapat dipakai untuk memecahkan persoalan atau fenomena terkait pembelajaran, selanjutnya siswa mempresentasikan discussion results di depan kelas ${ }^{[10]}$. Tahap yang terakhir adalah tahap pemantapan gagasan. Pada tahapan ini guru dapat memperkuat konsep yang telah dibangun oleh siswa. Dengan demikian yang pada awalnya konsep siswa tidak konsisten terhadap suatu konsep pembelajaran akan mengubahnya menjadi konsep ilmiah $^{[8]}$.

Pada kelas model 2, diterapkannya conventional learning model oleh guru dengan metode ceramah dan diskusi. Dalam pembelajaran tersebut siswa mendengarkan penjelasan dari guru terkait pembelajaran yang sedang berlangsung, selanjutnya siswa menjawab pertanyaan-pertanyaan yang ada di buku cetak atau sumber lainnya sesuai dengan topik pembelajaran $^{[11]}$. Skenario pembelajaran pada kelas sampel, dapat dilihat pada Tabel 8.

Tabel 8. Skenario Pembelajaran Kelas Sampel.

\begin{tabular}{|c|c|}
\hline Kelas A & Kelas B \\
\hline $\begin{array}{l}\text { 1. Kegiatan Awal } \\
\text { a. Guru mengawali } \\
\text { pelajaran dengan } \\
\text { menyampaikan } \\
\text { salam dan } \\
\text { mengecek } \\
\text { kehadiran. } \\
\text { b. Apersepsi. } \\
\text { c. Motivasi. }\end{array}$ & $\begin{array}{l}\text { 1. Kegiatan Awal } \\
\text { a. Guru mengawali } \\
\text { pelajaran dengan } \\
\text { menyampaikan } \\
\text { salam dan } \\
\text { mengecek } \\
\text { kehadiran. } \\
\text { b. Apersepsi. } \\
\text { c. Motivasi. }\end{array}$ \\
\hline $\begin{array}{l}\text { 2. Kegiatan Inti } \\
\text { Orientasi } \\
\text { a. Guru } \\
\text { menyampaikan } \\
\text { materi pokok } \\
\text { dan manfaat } \\
\text { mempelajari } \\
\text { materi tersebut. } \\
\text { b. Guru } \\
\text { menampilkan } \\
\text { fenomena } \\
\text { alam sesuai } \\
\text { dengan topik } \\
\text { pembelajaran. }\end{array}$ & $\begin{array}{l}\text { 2. Kegiatan Inti } \\
\text { a. Guru } \\
\text { menampilkan } \\
\text { sebuah video } \\
\text { mengenai topik } \\
\text { pembelajaran. } \\
\text { b. Guru } \\
\text { menampilkan } \\
\text { sebuah gambar } \\
\text { kepada siswa. }\end{array}$ \\
\hline
\end{tabular}




\begin{tabular}{|c|c|}
\hline Kelas A & Kelas B \\
\hline $\begin{array}{l}\text { Pemunculan } \\
\text { Gagasan } \\
\text { a. Guru membagi } \\
\text { kelompok diskusi. } \\
\text { b. Guru meminta } \\
\text { siswa untuk } \\
\text { mencatat } \\
\text { mengenai topik } \\
\text { pembelajaran } \\
\text { yang dibahas. }\end{array}$ & $\begin{array}{l}\text { c. Guru menjelaskan } \\
\text { materi } \\
\text { pembelajaran. } \\
\text { d. Siswa diminta } \\
\text { oleh guru untuk } \\
\text { berdiskusi } \\
\text { mengenai } \\
\text { pertanyaan- } \\
\text { pertanyaan yang } \\
\text { ada di buku cetak. } \\
\text { e. Guru dengan } \\
\text { siswa membahas } \\
\text { pertanyaan- } \\
\text { pertanyaan yang } \\
\text { terdapat dalam } \\
\text { buku cetak. }\end{array}$ \\
\hline $\begin{array}{l}\text { Penyusunan Ulang } \\
\text { Gagasan } \\
\text { a. Pemaparan dan } \\
\text { peralihan idea. } \\
\text { b. Pembukaan pada } \\
\text { situasi konflik. } \\
\text { c. Menyusun idea } \\
\text { baru. }\end{array}$ & \\
\hline $\begin{array}{l}\text { Penerapan Gagasan } \\
\text { a. Guru membimbing } \\
\text { siswa untuk } \\
\text { mengaplikasikan } \\
\text { idea baru yang } \\
\text { telah didapatkan, } \\
\text { guna menganalisis } \\
\text { problem solving. }\end{array}$ & \\
\hline $\begin{array}{l}\text { Pemantapan } \\
\text { Gagasan } \\
\text { a. Guru memberikan } \\
\text { feedback terhadap } \\
\text { hasil diskusi siswa. }\end{array}$ & \\
\hline $\begin{array}{l}\text { 3. Penutup } \\
\text { a. Siswa } \\
\text { menyimpulkan } \\
\text { materi } \\
\text { pembelajaran } \\
\text { dengan bimbingan } \\
\text { guru. }\end{array}$ & $\begin{array}{l}\text { 3. Penutup } \\
\text { a. Siswa } \\
\text { menyimpulkan } \\
\text { materi } \\
\text { pembelajaran } \\
\text { dengan bimbingan } \\
\text { guru. }\end{array}$ \\
\hline
\end{tabular}

\section{SIMPULAN}

Proses pembelajaran dengan model pembelajaran Children Learning In Science memberi pengaruh positif terhadap learning outcomes siswa pada materi larutan elektrolit dan non elektrolit, di mana learning outcomes siswa secara signifikan lebih tinggi jika menggunakan model CLIS dibandingkan model konvensional di SMAN 1 Padang pada alpha 0,05 .

\section{REFERENSI}

1. Fatmawati E. Pengembangan LKS Berbasis Children Learning In Science ( CLIS ) Untuk Meningkatkan Pemahaman Konsep dan Keterampilan Berfikir Kritis Siswa SMA. Yogyakarta: Universitas Negeri Yogyakarta; 2017.

2. Iriyanti NP, Mulyani S. Identifikasi

Miskonsepsi Pada Materi Pokok Wujud Zat Siswa Kelas VII SMP Negeri 1 Bawang Tahun Ajaran 2009/2010. 2012;1(1):8-13.

3. Laili Yanuari N. Pengaruh Model Children Learning In Science(Clis) Disertai LKS Berbasis Multirepresentasi Terhadap Aktivitas Belajar Siswa dan Hasil Belajar Siswa Dalam Pembelajaran Fisika di SMA Kabupaten Jember. J Pembelajaran Fis. 2015;4(2):171-5.

4. Nurseha. Pengaruh Model Pembelajaran Children Learning In Science Terhadap Keterampilan Proses Sains Dan Pemahaman Konsep Tentang Getaran dan Gelombang Pada Kelas VII SMP Negeri 5 Marawola. e-jurnal mitra sains. 2015;3(1):9-19.

5. Fatmawati E. Pengembangan LKS Berbasis Children Learning In Science ( CLIS ) Untuk Meningkatkan Pemahaman Konsep dan Keterampilan Berfikir Kritis Siswa SMA. J Pendidik Fis. 2017;6(1):41-9.

6. Sugiyono. Metode Penelitian Kuantitatif, Kualitatif, dan R\&D. Bandung: Alfabeta; 2011.

7. Sudjana N. Metode Statistika. Bandung: Tarsito; 2005.

8. Wardani TWW. Keefektifan Model CLIS (Children Learning In Science) Terhadap Aktivitas dan Hasil Belajar Energi Siswa Kelas III SDN 01 Cikawung. Semarang: Universitas Negeri Semarang; 2015.

9. Rustaman. Materi dan Pembelajaran IPA SD. Jakarta: Universitas Terbuka; 2011.

10. Hidayati. Peningkatan Hasil Belajar Siswa Melalui Model Children Learning In Science (CLIS) di Kelas XI IPA SMA Negeri 3 Palembang. J Pendidik Kim. 2015;2(2):23-34.

11. Muchitch S. Pembelajaran Kontekstual. Semarang: Rasail Media Group; 2008.

12. Nurhasanah S. Minat Belajar Sebagai Determinan Hasil Belajar Siswa. Pendidikan Manajemen Perkantoran. 2016;1(1):128-135 